\title{
PENGARUH KREATIVITAS BELAJAR, PERSEPSI SISWA TENTANG METODE MENGAJAR GURU, DAN LINGKUNGAN TEMAN SEBAYA TERHADAP PRESTASI BELAJAR AKUNTANSI DASAR SISWA KELAS X AKUNTANSI DAN KEUANGAN LEMBAGA SMK NEGERI 1 PENGASIH TAHUN AJARAN 2018/2019
}

\author{
THE EFFECT OF LEARNING CREATIVITY, STUDENT PERCEPTION OF \\ TEACHERS' TEACHING METHODS, AND PEER ENVIRONMENT TOWARDS \\ ACHIEVEMENT OF BASIC ACCOUNTING STUDENT IN CLASS X ACCOUNTING \\ AND FINANCIAL INSTITUTIONS SMK N 1 PENGASIH ACADEMIC YEAR 2018/2019
}

\author{
Oleh: \\ Zulfa Ainun Naim \\ Prodi Pendidikan Akuntansi Universitas Negeri Yogyakarta \\ zulfaainunnaim@gmail.com \\ Moh. Djazari \\ Staf Pengajar Jurusan Pendidikan Akuntansi Universitas Negeri Yogyakarta
}

\begin{abstract}
Abstrak
Penelitian ini bertujuan untuk mengetahui: 1) pengaruh Kreativitas Belajar terhadap Prestasi Belajar Akuntansi Dasar, 2) pengaruh Persepsi Siswa tentang Metode Mengajar Guru terhadap Prestasi Belajar Akuntansi Dasar, 3) pengaruh Lingkungan Teman Sebaya terhadap Prestasi Belajar Akuntansi Dasar, dan 4) pengaruh Kreativitas Belajar, Persepsi Siswa tentang Metode Mengajar Guru, dan Lingkungan Teman Sebaya secara bersama-sama terhadap Prestasi Belajar Akuntansi Dasar Siswa Kelas X AKL SMK Negeri 1 Pengasih Tahun Ajaran 2018/2019. Penelitian ini merupakan jenis penelitian ex post facto dengan pendekatan kuantitatif. Populasi dalam penelitian ini adalah Siswa Kelas X Akuntansi dan Keuangan Lembaga SMK Negeri 1 Pengasih Tahun Ajaran 2018/2019 sejumlah 64 siswa. Teknik pengumpulan data menggunakan dokumentasi dan kuisioner. Uji prasyarat analisis meliputi uji liniearitas dan uji multikolinearitas. Teknik analisis data yang digunakan adalah analisis regresi sederhana untuk hipotesis pertama, kedua, ketiga, dan analisis regresi ganda untuk hipotesis keempat. Hasil penelitian ini adalah: 1) Terdapat pengaruh positif Kreativitas Belajar terhadap Prestasi Belajar Akuntansi Dasar, dibuktikan dengan $\mathrm{r}_{\mathrm{x} 1 \mathrm{y}}=0,589 ; \mathrm{r}_{\mathrm{x} 1 \mathrm{y}}^{2}=0,347$; persamaan regresi $\mathrm{Y}=0,558 \mathrm{X}_{1}+32,836$; dan $\left.\mathrm{t}_{\mathrm{h}}=5,476>\mathrm{t}_{\mathrm{t}}=1,670,2\right)$ Terdapat pengaruh positif Persepsi Siswa tentang Metode Mengajar Guru terhadap Prestasi Belajar Akuntansi Dasar, dibuktikan dengan $\mathrm{r}_{\mathrm{x} 2 \mathrm{y}}=$ 0,$716 ; \mathrm{r}^{2}{ }_{\mathrm{x} 2 \mathrm{y}}=0,512$; persamaan regresi $\mathrm{Y}=0,561 \mathrm{X}_{2}+30,571$; dan $\left.\mathrm{t}_{\mathrm{h}}=8,072>\mathrm{t}_{\mathrm{t}}=1,670,3\right)$ Terdapat pengaruh positif Lingkungan Teman Sebaya terhadap Prestasi Belajar Akuntansi Dasar, dibuktikan dengan $r_{x 3 y}=0,718 ; r^{2}{ }_{x 1 y}=0,516$; persamaan garis regresi $Y=0,927 X_{3}+25,948 ;$ dan $t_{h}=8,123>t_{t}=$ 1,670. 4) Terdapat pengaruh positif Kreativitas Belajar, Persepsi Siswa tentang Metode Mengajar Guru, dan Lingkungan Teman Sebaya secara bersama-sama terhadap Prestasi Belajar Akuntansi Dasar, dibuktikan dengan $R_{y(1,2,3)}=0,838 ; R^{2}{ }_{y(1,2,3)}=0,703$; persamaan garis regresi $Y=0,158 X_{1}+$ $0,339 X_{2}+0,530 X_{3}+9,876 ;$ dan $F_{h}=47,310>F_{t}=2,760$ dengan total Sumbangan Efektif sebesar $70,30 \%$.
\end{abstract}

Kata kunci: Kreativitas Belajar, Persepsi Siswa tentang Metode Mengajar Guru, Lingkungan Teman Sebaya, Prestasi Belajar Akuntansi Dasar 


\section{Abstract}

This research aims to determine the effect of: 1) Learning Creativity on Achievement of Basic Accounting, 2) Student Perception of Teachers' Teaching Methods on Achievement of Basic Accounting, 3) Peer Environment on Achievement of Basic Accounting, and 4) Learning Creativity, Student Perception of Teacher Teaching Methods, and Peer Environment together towards Achievement of Basic Accounting Student in Class X Accounting and Financial Institutions SMK N 1 Pengasih Academic Year 2018/2019. This research used ex post facto type of research with a quantitative approach. The subject in this research were Class $X$ Accounting and Finance Institutions of SMK Negeri 1 Pengasih Academic Year 2018/2019, with total population 64 students. Data collection techniques used documentation and questionnaires. Analysis asumption tests include linearity test and multicollinearity test. The analysis technique used is simple regression analysis for the first, second, and third hypothesis, and multiple regression analysis for the fourth hypothesis. The results of the research show: 1) There is a positive effect of Learning Creativity on Achievement of Basic Accounting, as evidenced by $r_{x 1 y}=0.589 ; r_{x 1 y}^{2}=0.347$; the regression equation $Y=0.558 X_{1}+$ 32.836; and $\left.t_{h}=5,476>t_{t}=1,670,2\right)$ There is a positive influence on Student Perception of Teachers' Teaching Methods towards Achievement of Basic Accounting, as evidenced by $r_{x 2 y}=0.716 ; r_{x 2 y}^{2}=$ 0.512 ; the regression equation $Y=0.561 X_{2}+30.571$; and $t_{h}=8,072>t_{t}=1,670$. 3) There is $a$ positive effect of Peer Environment on Achievement of Basic Accounting, as evidenced by $r_{x 3 y}=0.718$; $r_{x l y}^{2}=0.516$; and the regression line equation $Y=0.927 X_{3}+25.948$; and $t_{h}=8,123>t_{t}=1,670.4$ ) There is a positive effect of Learning Creativity, Student Perception of Teachers' Teaching Methods, and Peer Environment together towards Achievement of Basic Accounting, as evidenced by $R_{y(1,2,3)}=$ 0,$838 ; R_{y(1,2,3)}^{2}=0,703$; the regression line equation $Y=0.158 X_{1}+0.339 X_{2}+0.530 X_{3}+9.876$; and $F_{h}=47,310>F_{t}=2,760$ with a total effective contribution was $70.30 \%$.

Keywords: Learning Creativity, Student Perception of Teachers' Teaching Methods, Peer Environment, Achievement of Basic Accounting

\section{PENDAHULUAN}

Pendidikan merupakan suatu proses mendasar dalam kehidupan manusia yang akan berlangsung sepanjang hayat. Manusia tidak akan bisa lepas dari pendidikan, di manapun manusia berada, di situlah terjadinya pendidikan. Setiap manusia berhak untuk mendapatkan pendidikan, karena pendidikan memegang peranan penting dalam kemajuan suatu bangsa. Salah satu tujuan kemerdekaan Indonesia adalah untuk mencerdaskan kehidupan bangsa sebagaimana tercantum dalam naskah Pembukaan UUD 1945. Hal tersebut menunjukkan bahwa salah satu fokus pembangunan Indonesia ada pada pendidikan. Menurut Siswoyo, dkk (2013: 46), pendidikan merupakan suatu kekuatan yang dinamis dalam memengaruhi kemampuan, kepribadian, dan kehidupan individu dalam pertemuan dan pergaulannya dengan sesama dan dunia, serta dalam hubungannya dengan Tuhan. Pendidikan berperan penting dalam penentuan kualitas generasi di suatu negara. Oleh karena itu perlu dilakukan suatu kegiatan yang dapat meningkatkan kualitas pendidikan di negeri ini salah satunya melalui penyelenggaraan pendidikan formal. Berdasarkan Peraturan Pemerintah Nomor 13 tahun 2015 tentang Standar Nasional Pendidikan, pendidikan formal adalah jalur pendidikan yang terstruktur dan berjenjang terdiri atas pendidikan dasar, pendidikan menengah, dan pendidikan tinggi. Berhasil tidaknya peserta didik dalam mengikuti pendidikan formal dapat dilihat dari prestasi belajar yang dicapai oleh peserta didik. Prestasi belajar digunakan sebagai pengukur tingkat pemahaman peserta didik terhadap materi yang diajarkan saat proses pembelajaran. Prestasi belajar yang optimal dapat dicapai apabila pembelajaran dilakukan secara efektif dan efisien. Sekolah Menengah Kejuruan (SMK) merupakan salah satu tempat pendidikan formal yang membekali peserta didik dengan kemampuan ilmu 
pengetahuan dan teknologi serta kecakapan kejuruan para profesi sesuai dengan kebutuhan masyarakat. Pada Sekolah Menengah Kejuruan (SMK) program keahlian Akuntansi dan Keuangan Lembaga, Akuntansi Dasar merupakan salah satu mata pelajaran dasar yang harus dikuasai oleh peserta didik sebelum mempelajari mata pelajaran produktif akuntansi yang lain. Berhasil tidaknya peserta didik dalam mempelajari Akuntansi Dasar dapat dilihat dari Prestasi Belajar Akuntansi Dasar.

Prestasi Belajar Akuntansi Dasar merupakan hasil yang dicapai oleh peserta didik yang memperlihatkan tingkat keberhasilan dalam pencapaian tujuan dari proses pembelajaran Akuntansi Dasar. Prestasi Belajar Akuntansi Dasar dapat dicapai siswa secara optimal melalui proses perubahan tingkah laku siswa sebagai hasil dari interaksi dengan lingkungan dikarenakan pengalaman yang didapatkan secara berulang-ulang. Pengukuran Prestasi Belajar Akuntansi Dasar peserta didik perlu dilakukan oleh guru agar dapat diketahui seberapa besar tingkat pencapaian peserta didik dalam menerima materi pelajaran Akuntansi Dasar yang disampaikan.

Prestasi Belajar Akuntansi Dasar diukur menggunakan tes yang dilaksanakan pada mata pelajaran Akuntansi Dasar. Tes tersebut terdiri dari tes formatif dan tes sumatif. Tes formatif digunakan untuk mengetahui sejauh mana siswa memahami pokok bahasan materi Akuntansi Dasar. Tes ini berupa Ulangan Harian (UH). Tes sumatif dilaksanakan untuk mengukur pemahaman peserta didik terhadap materi Akuntansi Dasar yang diajarkan selama setengah semester atau sering disebut Penilaian Tengah Semester (PTS) dan mengukur pemahaman peserta didik terhadap materi Akuntansi Dasar selama satu semester yaitu dengan Penilaian Akhir Semester (PAS).

Optimal atau tidaknya Prestasi Belajar Akuntansi Dasar peserta didik dipengaruhi oleh beberapa faktor, baik faktor dari dalam diri peserta didik maupun faktor yang berasal dari luar diri peserta didik. Faktor dari dalam diri peserta didik yang memengaruhi Prestasi Belajar Akuntansi Dasar terdiri dari faktor jasmaniah (kesehatan dan cacat tubuh), faktor psikologis (intelegensi, perhatian, minat, bakat, motif, kematangan, kesiapan, kreativitas), dan faktor kelelahan. Faktor dari luar diri peserta didik diantaranya faktor keluarga, faktor sekolah, dan faktor masyarakat. Berbagai faktor tersebut saling berhubungan satu dengan yang lain. Apabila faktor-faktor tersebut dapat terpenuhi dengan baik, maka peserta didik akan nyaman dalam belajar sehingga Prestasi Belajar Akuntansi Dasar akan semakin baik. Tinggi atau rendahnya Prestasi Belajar Akuntansi Dasar peserta didik dapat diukur menggunakan evaluasi yang dilakukan oleh guru. Evaluasi ini dapat berupa tes untuk mengukur Prestasi Belajar Akuntansi Dasar peserta didik setelah pembelajaran berlangsung. Siswa dapat dikatakan baik atau tidak dalam evaluasi belajar dapat ditentukan dengan menentukan Kriteria Ketuntasan Minimal (KKM).

Dari beberapa faktor dari dalam diri peserta didik yang memengaruhi Prestasi Belajar Akuntansi Dasar, Kreativitas Belajar merupakan faktor penting yang memengaruhi Prestasi Belajar Akuntansi Dasar. Kreativitas Belajar merupakan kemampuan yang dimiliki oleh siswa dalam menemukan hal baru yang digunakan untuk memecahkan masalah belajar atau tugas yang diberikan oleh guru. Siswa yang kurang dalam Kreativitas Belajar akan mengalami kesulitan dalam menangkap pelajaran diantaranya takut untuk menyampaikan pendapat yang berbeda dari temannya dan daya imajinatif yang kurang. Ada beberapa faktor yang memengaruhi Kreativitas Belajar sesorang siswa, yaitu faktor internal yang meliputi kondisi fisik, tingkat kecerdasan, dan kondisi mental serta faktor eksternal yang 
meliputi orang tua atau guru dapat menerima anak apa adanya, memberi kepercayaan, kesempatan kepada anak untuk mengungkapkan pikiran, perasaaan, dan pendapatnya, memupuk sikap dan minat anak dengan berbagai kegiatan positif, serta menyediakan sarana dan prasarana pendidikan.

Untuk mengukur Kreativitas Belajar siswa, ada beberapa indikator yang digunakan, yaitu ciri berpikir kreatif (aptitude) dan ciri afektif (non-aptitude). Ciri-ciri berpikir kreatif (aptitude) terdiri dari keterampilan berpikir lancar, keterampilan berpikir luwes, keterampilan berpikir rasional, dan keterampilan memperinci atau mengelaborasi. Untuk ciri-ciri afektif (non-aptitude) terdiri dari rasa ingin tahu yang tinggi, berani mengambil risiko, bersifat imajinatif, dan terbuka akan pengalaman baru.

Faktor internal lainnya yang berpengaruh terhadap Prestasi Belajar Akuntansi Dasar adalah Persepsi Siswa tentang Metode Mengajar Guru. Persepsi Siswa tentang Metode Mengajar Guru adalah proses masuknya pesan atau informasi mengenai metode yang digunakan guru untuk mengimplementasikan rencana pembelajaran Akuntansi Dasar yang telah disusun kepada siswa agar proses pembelajaran Akuntansi Dasar di kelas dapat dipahami oleh siswa dengan baik sehingga siswa merasa senang saat proses pembelajaran. Melalui persepsi manusia yang terus menerus akan menyebabkan adanya hubungan dengan lingkungan. Hubungan ini dapat dilakukan lewat indera penglihat, pendengar, peraba, perasa, dan pencium. Dapat disimpulkan bahwa proses persepsi diawali dari informasi, pesan, atau kegiatan suatu objek yang diterima oleh panca indera seseorang, yang selanjutnya akan berpengaruh terhadap reaksi seseorang tersebut atas informasi, pesan, atau kegiatan yang diperolehnya. Apabila dikaitkan dengan proses pembelajaran, suatu metode yang dilakukan oleh guru dalam menyampaikan materi pembelajaran tersebut akan memengaruhi perilaku siswa selama proses pembelajaran berlangsung.

Ada beberapa faktor yang memengaruhi Persepsi Siswa tentang Metode Mengajar Guru yaitu kepribadian guru yang bersangkutan, penguasaan bahan pembelajaran, penguasaan kelas, cara berbicara/komunikasi. Cara menciptakan suasana kelas/pengelolaan kelas, dan memperhatikan prinsip individualitas. Persepsi Siswa tentang Metode Mengajar Guru dapat diukur menggunakan beberapa indikator, yaitu persepsi sesuai dengan pengelolaan kelas, persepsi sesuai dengan tujuan pembelajaran yang ditentukan, persepsi sesuai dengan situasi pembelajaran, persepsi sesuai dengan fasilitas sekolah, dan persepsi sesuai dengan pemilihan metode mengajar guru yang disesuaikan dengan kemampuan guru. Lingkungan Teman Sebaya merupakan faktor eksternal yang memengaruhi Prestasi Belajar Akuntansi Dasar. Lingkungan Teman Sebaya adalah suatu lingkungan yang di dalamnya terdapat sekelompok orang yang mempunyai kesamaan usia maupun status dan mereka melakukan suatu interaksi yang dapat memberikan dampak baik positif maupun negatif. Intensitas pertemuan yang tinggi antar siswa ketika di sekolah berpengaruh terhadap suasana dari proses pembelajaran. Seorang anak menilai apa yang mereka lakukan dengan Lingkungan Teman Sebayanya, apakah dia lebih baik dari teman-temannya, sama, ataupun lebih buruk dibandingkan dengan temannya. Lingkungan Teman Sebaya yang baik akan memberikan dampak positif bagi diri seorang siswa dalam belajar, misalkan pembentukan kelompok belajar ataupun bertanya kepada teman mengenai materi yang belum dipahami karena siswa lebih nyaman apabila bertanya dengan teman sebayanya. Untuk mengukur seberapa besar pengaruh Lingkungan Teman Sebaya terhadap Prestasi Belajar Akuntansi Dasar, ada 
beberapa indikator yang dapat digunakan, yaitu interaksi sosial di Lingkungan Teman Sebaya, dukungan teman sebaya, keintiman atau kasih sayang antar teman sebaya, dan keterlibatan individu dalam berinteraksi.

SMK Negeri 1 Pengasih merupakan salah satu sekolah menengah kejuruan di Kabupaten Kulonprogo yang memiliki 6 program keahlian, yaitu: 1) Akuntansi dan Keuangan, 2) Administrasi Perkantoran, 3) Tata Niaga, 4) Tata Busana, 5) Multimedia dan 6) Akomodasi Perhotelan. Paket Keahlian di SMK Negeri 1 Pengasih untuk tahun 2018/2019 dengan penerapan Kurikulum 2013. Secara geografis SMK Negeri 1 Pengasih terletak di Jalan Kawijo 11, Pengasih, Kecamatan Pengasih, Kabupaten Kulonprogo, D.I Yogyakarta. Penelitian ini difokuskan pada siswa paket keahlian Akuntansi dan Keuangan Lembaga (AKL) yang di dalam pembelajarannya terdapat mata pelajaran Akuntansi Dasar. Pada mata pelajaran Akuntansi Dasar, Prestasi Belajar Akuntansi Dasar yang diperoleh siswa merupakan indikator keberhasilan proses belajar mengajar materi yang telah dipelajari. Berdasarkan observasi atau pengamatan pada siswa jurusan Akuntansi SMK Negeri 1 Pengasih pada 14 Desember 2018 pada aspek kognitif siswa diketahui bahwa mata pelajaran Akuntansi Dasar mempunyai Kriteria Ketuntasan Minimal (KKM) sebesar 75. Dari data Penilaian Tengah Semester (PTS) yang didapatkan, terdapat $64,06 \%$ atau 41 siswa belum mencapai KKM, sedangkan 35,93\% atau 23 siswa sudah mencapai KKM.

Kreativitas Belajar yang tinggi menjadi salah satu faktor internal dalam meningkatkan Prestasi Belajar Akuntansi Dasar. Tinggi rendahnya Kreativitas Belajar akan memengaruhi Prestasi Belajar Akuntansi Dasar yang didapatkan. Berdasarkan hasil observasi memperlihatkan kurangnya Kreativitas Belajar pada diri siswa pada proses pembelajaran diantaranya kurang aktifnya siswa dalam memberikan respon/tanggapan dari pertanyaan yang diberikan oleh guru. Sebesar $30 \%$ siswa harus diberikan rangsangan berupa petunjuk yang mengarah pada jawaban terlebih dahulu atau dengan kata lain siswa kurang kreatif dalam mencari sendiri jawaban atas pertanyaan yang diberikan oleh guru. Hal ini memperlihatkan bahwa Kreativitas Belajar Akuntansi Dasar masih tergolong rendah.

Faktor internal lainnya yang memengaruhi Prestasi Belajar Akuntansi Dasar adalah Persepsi Siswa tentang Metode Mengajar Guru. Persepsi positif dari siswa tentang metode mengajar yang diterapkan oleh guru akan membuat siswa senang dan bersemangat dalam mengikuti pembelajaran. Sebaliknya, persepsi negatif akan menyebabkan siswa bermalasmalasan dalam mengikuti pembelajaran. Observasi yang dilakukan di SMK Negeri 1 Pengasih dapat diketahui bahwa sekitar 45\% siswa memiliki persepsi yang kurang baik terhadap metode mengajar yang dilakukan oleh guru dikarenakan penggunaan metode pembelajaran ceramah menyebabkan siswa bosan dan memilih untuk berbicara dengan teman sebangkunya sehingga membuat kelas menjadi gaduh. Akibat dari persepsi buruk siswa terhadap metode mengajar guru di kelas membuat siswa kurang termotivasi untuk memperhatikan pelajaran dan memilih untuk melakukan hal lain seperti mengobrol dengan teman sebangkunya.

$\begin{array}{ccr}\text { Lingkungan } & \text { Teman Sebaya } \\ \text { merupakan faktor eksternal yang }\end{array}$
memengaruhi Prestasi Belajar Akuntansi Dasar. Pada observasi di SMK Negeri 1 Pengasih dapat dilihat bahwa Lingkungan Teman Sebaya mempunyai peranan yang sangat kuat dalam proses pembelajaran di kelas. Siswa yang duduk di depan cenderung tenang dan memperhatikan materi yang sedang disampaikan oleh guru karena teman sebangkunya melakukan hal yang sama. Berbeda dengan sebagian besar siswa yang duduk di meja nomor 2-4 atau 
sekitar $60 \%$ siswa kurang memperhatikan penjelasan guru dikarenakan berbicara sendiri dengan teman sebangkunya yang tidak berhubungan dengan materi yang disampaikan guru. Berdasarkan hal ini dapat dilihat bahwa Lingkungan Teman Sebaya mempunyai peranan yang sangat kuat dalam prestasi siswa di kelas. Apabila Lingkungan Teman Sebaya mempunyai kecenderungan yang positif, maka seorang siswa akan mempunyai prestasi belajar yang tinggi. Akan tetapi sebaliknya, apabila Lingkungan Teman Sebaya mempunyai kecenderungan negatif selama pembelajaran, maka akan memengaruhi temannya sehingga Prestasi Belajar Akuntansi Dasar menjadi rendah.

Berdasarkan uraian yang telah dijelaskan, peneliti ingin meneliti lebih lanjut tentang Prestasi Belajar Akuntansi Dasar yang diduga dipengaruhi oleh Kreativitas Belajar, Persepsi Siswa tentang Metode Mengajar Guru, dan Lingkungan Teman Sebaya. Untuk mengetahui seberapa besar pengaruh Kreativitas Belajar, Persepsi Siswa tentang Metode Mengajar Guru, dan Lingkungan Teman Sebaya terhadap Prestasi Belajar Akuntansi Dasar Siswa Kelas X Akuntansi dan Keuangan Lembaga SMK Negeri 1 Pengasih, maka peneliti bermaksud melakukan penelitian yang berjudul "Pengaruh Kreativitas Belajar, Persepsi Siswa tentang Metode Mengajar Guru, dan Lingkungan Teman Sebaya tehadap Prestasi Belajar Akuntansi Dasar Siswa Kelas X Akuntansi dan Keuangan Lembaga SMK Negeri 1 Pengasih Tahun Ajaran 2018/2019".

\section{METODE PENELITIAN Jenis Penelitian}

Penelitian ini merupakan jenis penelitian ex post facto yang bertujuan untuk mengetahui pengaruh antara variabel bebas yaitu Kreativitas Belajar, Persepsi Siswa tentang Metode Mengajar Guru, dan Lingkungan Teman Sebaya terhadap variabel terikat yaitu Prestasi Belajar
Akuntansi Dasar Siswa Kelas X Akuntansi dan Keuangan Lembaga SMK Negeri 1 Pengasih Tahun Ajaran 2018/2019. Pendekatan yang digunakan dalam penelitian ini adalah pendekatan kuantitatif yang menganalisis data angka menggunakan alat statistik.

\section{Tempat dan Waktu Penelitian}

Penelitian ini dilakukan di SMK Negeri 1 Pengasih yang beralamat di Jalan Kawijo 11, Pengasih, Kulonprogo, D.I Yogyakarta. Penelitian ini dilaksanakan pada Siswa Kelas $\mathrm{X}$ Akuntansi dan Keuangan Lembaga (AKL) SMK Negeri 1 Pengasih Tahun Ajaran 2018/2019. Pelaksanaan penelitian pada bulan Januari - Februari 2019.

\section{Populasi Penelitian}

Populasi dalam penelitian ini adalah seluruh Siswa Kelas X Akuntansi dan Keuangan Lembaga SMK Negeri 1 Pengasih Tahun Ajaran 2018/2019 yang terdiri dari 2 kelas dengan jumlah keseluruhan 64 siswa. Adapun perinciannya sebagai berikut:

Tabel 1. Data Siswa

\begin{tabular}{|c|c|}
\hline Kelas & Jumlah \\
\hline XI AKL 1 & 32 siswa \\
\hline XI AKL 2 & 32 siswa \\
\hline Total & 64 siswa \\
\hline
\end{tabular}

\section{Teknik Pengumpulan Data}

a. Dokumentasi

Penelitian ini menggunakan metode dokumentasi untuk memperoleh data dari variabel terikat yaitu Prestasi Belajar Akuntansi Dasar Siswa Kelas X Akuntansi dan Keuangan Lembaga SMK Negeri 1 Pengasih Tahun Ajaran 2018/2019.

b. Kuisioner (Angket)

Kuisioner digunakan untuk memperoleh data variabel bebas yaitu Kreativitas Belajar, Persepsi Siswa tentang Metode Mengajar Guru, dan Lingkungan Teman Sebaya. Kuisioner dalam penelitian ini menggunakan 
kuisioner tertutup di mana sudah terdapat beberapa jawaban yang sudah disediakan. Penyebaran kuisioner dilakukan secara langsung kepada responden guna memperoleh data dari variabel bebas yaitu Kreativitas Belajar, Persepsi Siswa tentang Metode Mengajar Guru, dan Lingkungan Teman Sebaya Siswa Kelas X Akuntansi dan Keuangan Lembaga SMK Negeri 1 Pengasih Tahun Ajaran 2018/2019.

\section{Instrumen Penelitian}

Instrumen yang digunakan dalam penelitian ini adalah dokumentasi dan angket. Dokumentasi digunakan untuk memperoleh data berupa nilai Penilaian Tengah Semester (PTS) dan Penilaian Akhir Semester (PAS) guna memperoleh informasi mengenai Prestasi Belajar Akuntansi Dasar, sedangkan kuisioner (angket) berisi pernyataan yang dijawab oleh responden untuk memperoleh informasi mengenai Kreativitas Belajar, Persepsi Siswa tentang Metode Mengajar Guru, dan Lingkungan Teman Sebaya Siswa Kelas X Akuntansi SMK Negeri 1 Pengasih Tahun Ajaran 2018/2019. Kuisioner (angket) yang digunakan merupakan angket tertutup, yaitu kuisioner (angket) yang telah dilengkapi dengan alternatif jawaban sehingga responden dapat memilih salah satu jawaban yang telah disediakan.

Pengukuran kuisioner (angket) menggunakan skala Likert yang dimodifikasi menjadi empat alternatif jawaban. Dengan skala Likert maka variabel yang akan diukur dijabarkan menjadi indikator variabel. Kemudian indikator tersebut dijadikan sebagai titik tolak untuk menyusun item-item instrumen yang dapat berupa pertanyaan atau pernyataan (Sugiyono, 2015:93). Skor setiap alternatif jawaban yang diberikan oleh responden adalah sebagai berikut:
Tabel 2. Skor Alternatif Jawaban

\begin{tabular}{|l|c|c|}
\hline \multirow{2}{*}{ Alterntif Jawaban } & \multicolumn{2}{|c|}{$\begin{array}{c}\text { Skor untuk } \\
\text { pernyataan }\end{array}$} \\
\cline { 2 - 3 } & Positif & Negatif \\
\hline Selalu (SL) & 4 & 1 \\
\hline Sering (SR) & 3 & 2 \\
\hline Jarang (JR) & 2 & 3 \\
\hline Tidak Pernah (TP) & 1 & 4 \\
\hline
\end{tabular}

\section{Uji Coba Instrumen}

Uji coba instrumen dilaksanakan sebelum instrumen tersebut digunakan dalam penelitian. Instrumen yang baik menurut Arikunto (2013: 211) adalah instrumen yang harus memenuhi dua persyaratan yaitu valid dan reliabel. Tujuan dilakukannya uji coba instrumen penelitian adalah untuk memperoleh informasi yang dapat diandalkan. Uji coba instrumen dalam penelitian ini dilaksanakan pada kelas X Akuntansi dan Keuangan Lembaga SMK Negeri 1 Bantul sebanyak 30 siswa. Siswa Kelas X Akuntansi dan Keuangan Lembaga SMK Negeri 1 Bantul dipilih sebagai subjek uji coba instrumen penelitian karena memiliki kesamaan karakteristik dengan siswa kelas $\mathrm{X}$ Akuntansi dan Keuangan Lembaga SMK Negeri 1 Pengasih, yaitu dalam hal samasama berstatus sekolah negeri, memiliki KKM dan akreditasi yang sama, dan kesamaan karakteristik siswa yakni faktorfaktor Prestasi Belajar Akuntansi Dasar yang belum optimal seperti Kreativitas Belajar, Persepsi Siswa tentang Metode Mengajar Guru, dan Lingkungan Teman Sebaya. Uji coba instrumen penelitian menggunakan dua pengujian, yaitu uji validitas dan uji reliabilitas.

\section{Teknik Analisis Data}

a. Uji Prasyarat Analisis

1) Uji Linearitas

Uji linearitas digunakan untuk mengetahui apakah variabel bebas (X) dan variabel terikat (Y) mempunyai hubungan linear atau tidak. Untuk mengetahui hal tersebut, kedua variabel diuji 
dengan $\mathrm{F}$ pada taraf signifikansi $5 \%$. Hasil dari $\mathrm{F}_{\text {hitung }}$ kemudian dibandingkan dengan $\mathrm{F}_{\text {tabel }}$ dengan taraf signifikansi 5\%. Apabila $\mathrm{F}_{\text {hitung }}$ lebih kecil atau sama dengan $\mathrm{F}_{\text {tabel}}$, berarti terdapat hubungan yang linier antara variabel bebas dan variabel terikat.

2) Uji Multikolinearitas

Uji multikolinearitas digunakan untuk memenuhi persyaratan analisis regresi ganda yaitu untuk mengetahui ada tidaknya variabel independen yang memiliki kemiripan dengan variabel independen lain dalam satu model. Teknik statistik yang digunakan adalah korelasi Product Moment dari Pearson. Apabila nilai koefisien korelasi antar variabel bebas kurang dari 0,700 maka dapat dikatakan terbebas dari asumsi klasik multikolinearitas. Apabila lebih dari 0,700 maka diasumsikan terjadi multikolinearitas antar variabel independen (Nugroho, 2006:58). Analisis regresi dapat dilanjutkan apabila koefisien korelasi antar variabel independen kurang dari 0,700 .

b. Pengujian Hipotesis

Pengujian Hipotesis pada penelitian ini menggunakan analisis regresi sederhana dan analisis regresi ganda. Analisis regresi sederhana digunakan untuk menguji hipotesis pertama yaitu terdapat pengaruh positif Kreativitas Belajar terhadap Prestasi Belajar Akuntansi Dasar Siswa Kelas X Akuntansi dan Keuangan Lembaga SMK Negeri 1 Pengasih Tahun Ajaran 2018/2019, hipotesis kedua yaitu terdapat pengaruh positif Persepsi Siswa tentang Metode Mengajar Guru terhadap Prestasi Belajar Akuntansi Dasar Siswa Kelas X Akuntansi dan Keuangan Lembaga SMK Negeri 1 Pengasih Tahun Ajaran 2018/2019, dan hipotesis ketiga yaitu terdapat pengaruh positif Lingkungan Teman Sebaya terhadap Prestasi Belajar Akuntansi Dasar Siswa Kelas X Akuntansi dan Keuangan Lembaga SMK Negeri 1 Pengasih Tahun Ajaran 2018/2019. Analisis regresi ganda digunakan untuk menguji hipotesis keempat, yaitu terdapat pengaruh positif Kreativitas Belajar, Persepsi Siswa tentang Metode Mengajar Guru, dan Lingkungan Teman Sebaya secara bersama-sama terhadap Prestasi Belajar Akuntansi Dasar Siswa Kelas $X$ Akuntansi dan Keuangan Lembaga SMK Negeri 1 Pengasih Tahun Ajaran 2018/2019.

\section{HASIL PENELITIAN DAN PEMBA- HASAN \\ Uji Prasyarat Analisis}

a. Uji Linearitas

Hasil uji linearitas menggunakan aplikasi statistik dirangkum dalam tabel 3 berikut:

Tabel 3. Rangkuman Hasil Uji Linearitas

\begin{tabular}{|c|c|c|c|c|c|}
\hline Variabel Bebas $(\mathbf{X})$ & Df & Fhitung & Ftabel $_{1}$ & Sig. & Ket. \\
\hline$X_{1}$ & $26 / 36$ & 1,208 & 1,806 & 0,295 & Linier \\
\hline$X_{2}$ & $31 / 31$ & 1,583 & 1,822 & 0,103 & Linier \\
\hline$X_{3}$ & $19 / 43$ & 1,025 & 1,834 & 0,455 & Linier \\
\hline
\end{tabular}

Berdasarkan Tabel. 3 di atas dapat diketahui bahwa $F_{\text {hitung }}<\mathrm{F}_{\text {tabel }}$ pada taraf signifikansi $5 \%$ sehingga dapat disimpulkan bahwa terdapat hubungan yang linier antara variabel bebas $(\mathrm{X})$ dengan variabel terikat $(\mathrm{Y})$. 
b. Uji Multikolinearitas

Hasil uji multikolinearitas menggunakan aplikasi statistik dirangkum dalam tabel 4 berikut:

Tabel 4. Ringkasan Hasil Uji Multikolinearitas

\begin{tabular}{|l|l|l|l|l|}
\hline \multirow{2}{*}{$\begin{array}{l}\text { Variabel } \\
\text { Bebas }(\mathbf{X})\end{array}$} & \multicolumn{3}{|l|}{ Koefisien Korelasi } & Keterangan \\
\cline { 2 - 5 } & $\mathbf{X}_{\mathbf{1}}$ & $\mathbf{X}_{\mathbf{2}}$ & $\mathbf{X}_{\mathbf{3}}$ & \\
\hline $\mathrm{X}_{1}$ & 1 & 0,461 & 0,544 & Tidak terjadi multikolinearitas \\
\hline $\mathrm{X}_{2}$ & 0,461 & 1 & 0,502 & Tidak terjadi multikolinearitas \\
\hline $\mathrm{X}_{3}$ & 0,544 & 0,502 & 1 & Tidak terjadi multikolinearitas \\
\hline
\end{tabular}

Berdasarkan Tabel 4 di atas dapat disimpulkan bahwa antar variabel Kreativitas Belajar $\left(\mathrm{X}_{1}\right)$ dan Persepsi Siswa tentang Metode Mengajar Guru $\left(\mathrm{X}_{2}\right)$ memiliki nilai korelasi sebesar $0,461<0,700$ sehingga tidak terjadi multikolinearitas antara $\mathrm{X}_{1}$ dan $\mathrm{X}_{2}$, antar variabel Kreativitas Belajar $\left(\mathrm{X}_{1}\right)$ dan Lingkungan Teman Sebaya $\left(\mathrm{X}_{3}\right)$ memiliki nilai korelasi sebesar 0,544 < 0,700 sehingga tidak terjadi multikolinearitas antara $\mathrm{X}_{1}$ dan $\mathrm{X}_{3}$, dan antar variabel Persepsi Siswa tentang Metode Mengajar Guru $\left(\mathrm{X}_{2}\right)$ dan Lingkungan Teman Sebaya $\left(\mathrm{X}_{3}\right)$ memiliki nilai korelasi sebesar $0,502<$ 0,700 sehingga tidak terjadi multikolinearitas antara $\mathrm{X}_{2}$ dan $\mathrm{X}_{3}$.

\section{Uji Hipotesis}

a. Hasil Pengujian Hipotesis Pertama

Rangkuman hasil pengujian hipotesis pertama dapat dilihat pada tabel 5 berikut ini:

Tabel 5. Rangkuman Hasil Pengujian Hipotesis Pertama

\begin{tabular}{|l|l|l|l|l|l|l|l|}
\hline \multicolumn{2}{|l|}{ Harga $\mathbf{r}-\mathbf{r}^{\mathbf{2}}$} & Koef. $\mathbf{X}_{1}$ & Konst. & thitung & $\mathbf{t}_{\text {tabel }}$ & Sig. & Ket. \\
\hline $\mathrm{r}_{\mathrm{x} 1 \mathrm{y}}$ & $\mathbf{r}_{\mathrm{x} 1 \mathrm{y}}^{2}$ & & & & & & \\
\hline 0,589 & 0,347 & 0,558 & 32,836 & 5,746 & 1,670 & 0,000 & Positif \\
\hline
\end{tabular}

Berdasarkan Tabel 5 tersebut, diketahui bahwa koefisien korelasi $\left(\mathrm{r}_{\mathrm{x} 1 \mathrm{y}}\right)$ bernilai positif sebesar 0,589 menunjukkan bahwa Kreativitas Belajar $\left(\mathrm{X}_{1}\right)$ memiliki hubungan positif terhadap Prestasi Belajar Akuntansi Dasar (Y). Koefisien determinasi $r^{2}{ }_{x 1 y}=0,347$ berarti Kreativitas Belajar $\left(\mathrm{X}_{1}\right)$ memengaruhi Prestasi Belajar Akuntansi Dasar (Y) sebesar 34,70\%, selebihnya sebesar 65,30\% Prestasi Belajar Akuntansi Dasar dipengaruhi oleh faktor atau variabel selain Kreativitas Belajar. Besarnya koefisien Kreativitas Belajar $\left(\mathrm{X}_{1}\right)$ sebesar 0,558 dan bilangan konstanta sebesar 32,836. Angka- angka tersebut selanjutnya dibuat garis persamaan regresi yaitu $\mathrm{Y}=0,558 \mathrm{X}_{1}+$ 32,836. Berdasarkan hasil perhitungan dengan rumus $t$, diperoleh $t_{\text {hitung }}$ sebesar 5,746 $>t_{\text {tabel }} 1,670$ pada taraf signifikansi 5\%. Dari hasil tersebut, maka hipotesis pertama yaitu "terdapat pengaruh positif Kreativitas Belajar terhadap Prestasi Belajar Akuntansi Dasar Siswa Kelas X Akuntansi dan Keuangan Lembaga SMK Negeri 1 Pengasih Tahun Ajaran 2018/2019" diterima. 
b. Hasil Pengujian Hipotesis Kedua

Rangkuman hasil pengujian hipotesis kedua dapat dilihat pada tabel 6 berikut ini:

Tabel 6. Rangkuman Hasil Pengujian Hipotesis Kedua

\begin{tabular}{|l|l|l|l|l|l|l|l|}
\hline \multicolumn{2}{|l|}{ Harga $\mathbf{r}-\mathbf{r}^{\mathbf{2}}$} & Koef. $\mathbf{X}_{\mathbf{2}}$ & Konst. & $\mathbf{t}_{\text {hitung }}$ & $\mathbf{t}_{\text {tabel }}$ & Sig. & Ket. \\
\hline $\mathbf{r}_{\mathbf{x} 2 \mathbf{y}}$ & $\mathbf{r}^{\mathbf{2}} \mathbf{x 2 \mathbf { y }}$ & & & & & & \\
\hline 0,716 & 0,512 & 0,561 & 30,571 & 8,072 & 1,670 & 0,000 & Positif \\
\hline
\end{tabular}

Berdasarkan Tabel 6 tersebut dapat diketahui bahwa koefisien korelasi $\left(\mathrm{r}_{\mathrm{x} 2 \mathrm{y}}\right)$ bernilai positif sebesar 0,716 , menunjukkan bahwa Persepsi Siswa tentang Metode Mengajar Guru $\left(\mathrm{X}_{2}\right)$ memiliki hubungan positif terhadap Prestasi Belajar Akuntansi Dasar (Y). Koefisien determinasi $\mathrm{r}_{\mathrm{x} 2 \mathrm{y}}^{2}=0,512$ berarti Persepsi Siswa tentang Metode Mengajar Guru $\left(\mathrm{X}_{2}\right)$ memengaruhi Prestasi Belajar Akuntansi Dasar (Y) sebesar 51,20\%, selebihnya sebesar 48,80\% Prestasi Belajar Akuntansi Dasar dipengaruhi oleh faktor atau variabel selain Persepsi Siswa tentang Metode Mengajar Guru. Besarnya koefisien Persepsi Siswa tentang Metode Mengajar Guru $\left(\mathrm{X}_{2}\right)$ sebesar 0,561 dan bilangan konstanta sebesar 30,571. Angka-angka tersebut selanjutnya dibuat garis persamaan regresi yaitu $\mathrm{Y}=0,561 \mathrm{X}_{2}+30,571$. Berdasarkan hasil perhitungan dengan rumus $\mathrm{t}$, diperoleh thitung sebesar 8,072 $>t_{\text {tabel }} 1,670$ pada taraf signifikansi $5 \%$. Dari hasil tersebut, maka hipotesis kedua yaitu "terdapat pengaruh positif Persepsi Siswa tentang Metode Mengajar Guru terhadap Prestasi Belajar Akuntansi Dasar Siswa Kelas X Akuntansi dan Keuangan Lembaga SMK Negeri 1 Pengasih Tahun Ajaran 2018/2019" diterima.

c. Hasil Pengujian Hipotesis Ketiga

Rangkuman hasil pengujian hipotesis ketiga dapat dilihat pada tabel 7 berikut ini:

Tabel 7. Rangkuman Hasil Pengujian Hipotesis Ketiga

\begin{tabular}{|c|c|c|c|c|c|c|c|}
\hline \multicolumn{2}{|c|}{ Harga $\mathbf{r}-\mathbf{r}^{\mathbf{2}}$} & Koef. $\mathbf{X}_{\mathbf{3}}$ & Konst. & $\mathbf{t}_{\text {hitung }}$ & $\mathbf{t}_{\text {tabel }}$ & Sig. & Ket. \\
\hline $\mathbf{r}_{\mathbf{x} 3 \mathbf{y}}$ & $\mathbf{r}_{\mathbf{2} 3 \mathbf{3}}$ & & & & & & \\
\hline 0,718 & 0,516 & 0,927 & 25,948 & 8,123 & 1,670 & 0,000 & Positif \\
\hline
\end{tabular}

Berdasarkan Tabel 7 tersebut dapat diketahui bahwa koefisien korelasi $\left(r_{x 3 y}\right)$ bernilai positif sebesar 0,718 , menunjukkan bahwa Lingkungan Teman Sebaya $\left(\mathrm{X}_{3}\right)$ memiliki hubungan positif terhadap Prestasi Belajar Akuntansi Dasar (Y). Koefisien determinasi $r_{x 3 y}^{2}=0,516$ berarti Lingkungan Teman Sebaya $\left(\mathrm{X}_{3}\right)$ memengaruhi Prestasi Belajar Akuntansi Dasar (Y) sebesar 51,60\%, selebihnya sebesar $48,40 \%$ Prestasi
Belajar Akuntansi Dasar dipengaruhi oleh faktor atau variabel selain Lingkungan Teman Sebaya. Besarnya koefisien Lingkungan Teman Sebaya $\left(\mathrm{X}_{3}\right)$ sebesar 0,927 dan bilangan konstanta sebesar 25,948. Angkaangka tersebut selanjutnya dibuat garis persamaan regresi yaitu $\mathrm{Y}=0,927 \mathrm{X}_{3}+$ 25,948. Berdasarkan hasil perhitungan dengan rumus $t$, diperoleh $t_{\text {hitung }}$ sebesar 8,123 $>\mathrm{t}_{\text {tabel }} 1,670$ pada taraf signifikansi $5 \%$. Dari hasil tersebut, 
maka hipotesis ketiga yaitu "terdapat pengaruh positif Lingkungan Teman Sebaya terhadap Prestasi Belajar Akuntansi Dasar Siswa Kelas X Akuntansi dan Keuangan Lembaga
SMK Negeri 1 Pengasih Tahun Ajaran 2018/2019" diterima.

d. Hasil Pengujian Hipotesis Keempat

Rangkuman hasil pengujian hipotesis keempat dapat dilihat pada tabel 8 berikut ini:

Tabel 8. Rangkuman Hasil Pengujian Hipotesis Keempat

\begin{tabular}{|c|c|c|c|c|c|c|}
\hline Sumber & Koef. & $R_{\mathbf{y}(1,2,3)}$ & $R^{2} \mathbf{y}(1,2,3)$ & $F_{h}$ & $F_{t}$ & Ket \\
\hline Konstanta & 9,876 & & & & & \multirow{4}{*}{ Positif } \\
\hline $\mathrm{X}_{1}$ & 0,158 & \multirow{3}{*}{0,838} & \multirow{3}{*}{0,703} & \multirow{3}{*}{47,310} & \multirow{3}{*}{2,760} & \\
\hline$X_{2}$ & 0,339 & & & & & \\
\hline$X_{3}$ & 0,530 & & & & & \\
\hline
\end{tabular}

Berdasarkan Tabel 8 tersebut diketahui bahwa koefisien korelasi bernilai positif $\mathrm{R}_{\mathrm{y}(1,2,3)}=0,838$ menunjukkan bahwa Kreativitas Belajar $\left(\mathrm{X}_{1}\right)$, Persepsi Siswa tentang Metode Mengajar Guru $\left(\mathrm{X}_{2}\right)$, dan Lingkungan Teman Sebaya $\left(\mathrm{X}_{3}\right)$ secara bersamasama memiliki hubungan positif terhadap Prestasi Belajar Akuntansi Dasar (Y). Koefisien determinasi $\mathrm{R}_{\mathrm{y}(1,2,3)}^{2}=0,703$ berarti Kreativitas Belajar $\left(\mathrm{X}_{1}\right)$, Persepsi Siswa tentang Metode Mengajar Guru $\left(\mathrm{X}_{2}\right)$, dan Lingkungan Teman Sebaya $\left(\mathrm{X}_{3}\right)$ secara bersama-sama memengaruhi Prestasi Belajar Akuntansi Dasar (Y) sebesar $70,30 \%$, selebihnya sebesar $29,70 \%$ Prestasi Belajar Akuntansi Dasar dipengaruhi oleh faktor atau variabel selain Kreativitas Belajar, Persepsi Siswa tentang Metode Mengajar Guru, Lingkungan Teman Sebaya. Besarnya koefisien Kreativitas Belajar $\left(\mathrm{X}_{1}\right)$ sebesar 0,158, Persepsi Siswa tentang Metode Mengajar Guru $\left(\mathrm{X}_{2}\right)$ sebesar 0,339, dan Lingkungan Teman Sebaya $\left(\mathrm{X}_{3}\right)$ sebesar 0,530 dan bilangan konstanta sebesar 9,876. Angka-angka tersebut selanjutnya dibuat garis persamaan regresi ganda yaitu $\mathrm{Y}=$ $0,158 X_{1}+0,339 X_{2}+0,530 X_{3}+9,876$.

Berdasarkan uji $F$, diperoleh $F_{\text {hitung }}$ sebesar 47,310> $\mathrm{F}_{\text {tabel }}$ sebesar 2,760 pada taraf signifikansi $5 \%$. Dari hasil tersebut, maka hipotesis keempat yaitu "terdapat pengaruh positif Kreativitas Belajar, Persepsi Siswa tentang Metode Mengajar Guru, dan Lingkungan Teman Sebaya secara bersama-sama terhadap Prestasi Belajar Akuntansi Dasar Siswa Kelas X Akuntansi dan Keuangan Lembaga SMK Negeri 1 Pengasih Tahun Ajaran 2018/2019” diterima.

e. Sumbangan Relatif dan Sumbangan Efektif

Sumbangan Relatif (SR) digunakan untuk mengetahui seberapa besar sumbangan masing-masing variabel bebas (Kreativitas Belajar, Persepsi Siswa tentang Metode Mengajar Guru, dan Lingkungan Teman Sebaya) terhadap variabel terikat (Prestasi Belajar Akuntansi Dasar) yang diteliti. Hasil perhitungan Sumbangan Relatif (SR) adalah sebagai berikut:

Tabel 9. Hasil

Perhitungan Sumbangan Relatif (SR)

\begin{tabular}{|c|l|c|}
\hline No & \multicolumn{1}{|c|}{$\begin{array}{c}\text { Nama } \\
\text { Variabel }\end{array}$} & $\begin{array}{c}\text { Sumbangan } \\
\text { Relatif (SR) }\end{array}$ \\
\hline 1 & $\mathrm{X}_{1}$ & $17,70 \%$ \\
\hline 2 & $\mathrm{X}_{2}$ & $40,11 \%$ \\
\hline 3 & $\mathrm{X}_{3}$ & $42,19 \%$ \\
\hline \multicolumn{2}{|c|}{ Jumlah } & $100,00 \%$ \\
\hline
\end{tabular}

Berdasarkan Tabel 9 tersebut dapat diketahui bahwa Sumbangan Relatif 
(SR) untuk variabel Kreativitas Belajar terhadap Prestasi Belajar Akuntansi Dasar adalah sebesar $17,70 \%$, variabel Persepsi Siswa tentang Metode Mengajar Guru terhadap Prestasi Belajar Akuntansi Dasar sebesar $40,11 \%$, dan variabel Lingkungan Teman Sebaya terhadap Prestasi Belajar Akuntansi Dasar sebesar 43,19\%.

Sumbangan Efektif (SE) digunakan untuk mengetahui seberapa besar Sumbangan Efektif masing-masing variabel bebas (Kreativitas Belajar, Persepsi Siswa tentang Metode Mengajar Guru, dan Lingkungan Teman Sebaya) terhadap variabel terikat (Prestasi Belajar Akuntansi Dasar) yang diteliti. Hasil perhitungan Sumbangan Efektif (SE) adalah sebagai berikut:

Tabel 10. Hasil

Perhitungan Sumbangan Efektif (SE)

\begin{tabular}{|c|l|c|}
\hline No & $\begin{array}{c}\text { Nama } \\
\text { Variabel }\end{array}$ & $\begin{array}{c}\text { Sumbangan } \\
\text { Efektif (SE) }\end{array}$ \\
\hline 1 & $\mathrm{X}_{1}$ & $12,44 \%$ \\
\hline 2 & $\mathrm{X}_{2}$ & $28,20 \%$ \\
\hline 3 & $\mathrm{X}_{3}$ & $29,66 \%$ \\
\hline \multicolumn{2}{|c|}{ Jumlah } & $70,30 \%$ \\
\hline
\end{tabular}

Berdasarkan Tabel 10 tersebut dapat diketahui diketahui bahwa Sumbangan Efektif (SE) untuk variabel Kreativitas Belajar terhadap Prestasi Belajar Akuntansi Dasar adalah sebesar 12,44\%, variabel Persepsi Siswa tentang Metode Mengajar Guru terhadap Prestasi Belajar Akuntansi Dasar sebesar 28,20\%, dan variabel Lingkungan Teman Sebaya terhadap Prestasi Belajar Akuntansi Dasar sebesar 29,66\%. Variabel Kreativitas Belajar, Persepsi Siswa tentang Metode Mengajar Guru, dan Lingkungan Teman Sebaya secara bersama-sama memberikan Sumbangan Efektif (SE) sebesar 70,30\% terhadap Prestasi Belajar Akuntansi Dasar dan sebesar
$29,70 \%$ diberikan oleh variabel lain yang tidak diteliti dalam penelitian ini.

\section{Pembahasan}

a. Pengaruh Kreativitas Belajar terhadap Prestasi Belajar Akuntansi Dasar Siswa Kelas X Akuntansi dan Keuangan Lembaga SMK Negeri 1 Pengasih Tahun Ajaran 2018/2019

Hasil penelitian ini menunjukkan bahwa variabel Kreativitas Belajar berpengaruh positif terhadap Prestasi Belajar Akuntansi Dasar Siswa Kelas X Akuntansi dan Keuangan Lembaga SMK Negeri 1 Pengasih Tahun Ajaran 2018/2019. Berdasarkan hasil analisis regresi sederhana diperoleh persamaan garis regresi sederhana $\mathrm{Y}=0,558 \mathrm{X}_{1}+$ 32,836 . Harga koefisien korelasi $\left(\mathrm{r}_{\mathrm{x} 1 \mathrm{y}}\right)$ bernilai positif sebesar 0,589 dan koefisien determinasi $\left(\mathrm{r}^{2} \mathrm{x} 1 \mathrm{y}\right)$ sebesar 0,347 berarti bahwa Kreativitas Belajar memberikan pengaruh sebesar $34,70 \%$ terhadap Prestasi Belajar Akuntansi Dasar dan sebesar 65,30\% dipengaruhi oleh variabel lain yang tidak diteliti.

Hasil penelitian ini diperkuat dengan kajian teori dan penelitian yang relevan. Kreativitas Belajar merupakan salah satu faktor dari dalam diri siswa yang dapat memengaruhi hasil dari proses pembelajaran. Menurut Yusuf dan Nurihsan (2005: 246) kreativitas dapat diartikan sebagai kemampuan untuk memberikan gagasan baru dan menerapkannya dalam pemecahan masalah. Jadi dapat disimpulkan bahwa kreativitas belajar merupakan kemampuan yang dimiliki siswa untuk memberikan gagasan-gagasan baru yang berasal dari pengalaman sendiri dalam interaksi dengan lingkungan yang digunakan untuk memecahkan suatu masalah belajar yang dialami. Pemecahan masalah belajar yang dimaksud adalah kemampuan siswa untuk mengerjakan soal Akuntansi 
Dasar yang diberikan oleh guru. Berdasarkan data yang diperoleh melalui pengisian angket, berani memberikan masukan kepada guru terkait proses pembelajaran Akuntansi Dasar agar pembelajaran lebih baik kedepannya memiliki jumlah skor terendah. Hal ini berarti siswa kurang berani mengambil risiko. Oleh karena itu, diharapkan siswa agar lebih berani untuk menyampaikan pendapat terkait dengan proses pembelajaran di kelas dan memberikan masukan kepada guru agar proses pembelajaran di kelas menjadi lebih baik kedepannya sehingga Prestasi Belajar Akuntansi Dasar yang didapatkan meningkat.

Hasil penelitian ini juga diperkuat oleh penelitian yang dilakukan Afrial Irfa' (2017) yang berjudul "Pengaruh Motivasi Belajar, Kreativitas Belajar, dan Lingkungan Teman Sebaya terhadap Prestasi Belajar Akuntansi Keuangan Siswa Kelas XI Akuntansi SMK Negeri 1 Tempel Tahun Ajaran 2016/2017". Hasil penelitian menunjukkan terdapat pengaruh positif Kreativitas Belajar terhadap Prestasi Belajar Akuntansi Keuangan Siswa Kelas XI Akuntansi SMK Negeri 1 Tempel Tahun Ajaran 2016/2017 yang dibuktikan dengan koefisien korelasi $\left(\mathrm{r}_{\mathrm{x} 2 \mathrm{y}}\right)$ sebesar 0,604, koefisien determinasi $\left(\mathrm{r}^{2} \times 2 \mathrm{y}\right)$ sebesar 0,365 yang artinya variabel ini memengaruhi Prestasi Belajar Akuntansi Keuangan sebesar 36,5\%. Persamaan garis regresi $\mathrm{Y}=0,787 \mathrm{X}_{2}+38,193$.

b. Pengaruh Persepsi Siswa tentang Metode Mengajar Guru terhadap Prestasi Belajar Akuntansi Dasar Siswa Kelas X Akuntansi dan Keuangan Lembaga SMK Negeri 1 Pengasih Tahun Ajaran 2018/2019

Hasil penelitian ini menunjukkan bahwa variabel Persepsi Siswa tentang Metode Mengajar Guru berpengaruh positif terhadap Prestasi Belajar
Akuntansi Dasar Siswa Kelas X Akuntansi dan Keuangan Lembaga SMK Negeri 1 Pengasih Tahun Ajaran 2018/2019. Berdasarkan hasil analisis regresi sederhana diperoleh persamaan garis regresi sederhana $\mathrm{Y}=0,561 \mathrm{X}_{2}+$ 30,571. Harga koefisien korelasi $\left(\mathrm{r}_{\mathrm{x} 2 \mathrm{y}}\right)$ bernilai positif sebesar 0,716 dan koefisien determinasi $\left(\mathrm{r}^{2} \times 2 \mathrm{y}\right)$ sebesar 0,512 berarti bahwa Persepsi Siswa tentang Metode Mengajar Guru memberikan pengaruh sebesar $51,20 \%$ terhadap Prestasi Belajar Akuntansi Dasar dan sebesar 48,80\% dipengaruhi oleh variabel lain yang tidak diteliti.

Hasil penelitian ini diperkuat dengan kajian kajian teori dan penelitian yang relevan. Menurut Slameto (2015: 102) persepsi adalah proses yang menyangkut masuknya pesan atau informasi ke dalam otak manusia, sedangkan metode mengajar menurut Sudjana (2004: 76) yaitu cara yang dipergunakan guru dalam mengadakan hubungan dengan siswa pada saat berlangsungnya pengajaran. Terdapat dua macam Persepsi Siswa tentang Metode Mengajar Guru, yaitu persepsi positif dan negatif. Apabila Persepsi Siswa tentang Metode Mengajar Guru positif, maka siswa antusias dalam mengikuti pembelajaran di kelas. Sebaliknya, apabila Persepsi Siswa tentang Metode Mengajar Guru negatif, maka siswa merasa kurang bersemangat dalam mengikuti pembelajaran sehingga Prestasi Belajar Akuntansi Dasar menjadi kurang maksimal. Berdasarkan data yang diperoleh melalui pengisian angket, guru menggunakan media pembelajaran yang bervariasi saat menjelaskan materi Akuntansi Dasar memiliki jumlah skor terendah. Oleh karena itu, variasi metode mengajar oleh guru sangat penting agar siswa tidak merasa bosan selama pembelajaran. Guru juga perlu memilih metode pembelajaran 
yang dapat membuat siswa merasa antusias dalam belajar agar siswa lebih memahami materi yang diajarkan sehingga Prestasi Belajar Akuntansi Dasar akan meningkat.

Hasil penelitian ini juga diperkuat oleh penelitiann yang dilakukan Hanung Nawang Palupi (2018) yang berjudul "Pengaruh Lingkungan Keluarga, Minat Belajar, dan Persepsi Siswa pada Metode Mengajar Guru terhadap Prestasi Belajar Akuntansi Dasar Siswa Jurusan Akuntansi SMK Abdi Negara Muntilan Tahun Ajaran 2017/2018". Hasil penelitian menunjukkan bahwa terdapat pengaruh positif Persepsi Siswa pada Metode Mengajar Guru terhadap Prestasi belajar Akuntasi Dasar Siswa Jurusan Akuntansi SMK Abdi Negara Muntilan Tahun Ajaran 2017/2018, terlihat dari hasil koefisien yang positif nilai koefisien korelasi $r_{x 3 y}=0,744$; koefisien determinasi $r^{2}{ }_{x 3 y}=0,554$, dengan persamaan regresi $\mathrm{Y}=4,024+$ $0,977 X_{3}$.

c. Pengaruh Lingkungan Teman Sebaya terhadap Prestasi Belajar Akuntansi Dasar Siswa Kelas X Akuntansi dan Keuangan Lembaga SMK Negeri 1 Pengasih Tahun Ajaran 2018/2019

Hasil penelitian ini menunjukkan bahwa variabel Lingkungan Teman Sebaya berpengaruh positif terhadap Prestasi Belajar Akuntansi Dasar Siswa Kelas X Akuntansi dan Keuangan Lembaga SMK Negeri 1 Pengasih Tahun Ajaran 2018/2019. Berdasarkan hasil analisis regresi sederhana diperoleh persamaan garis regresi sederhana $\mathrm{Y}=0,927 \mathrm{X}_{3}+$ 25,948 . Harga koefisien korelasi $\left(\mathrm{r}_{\mathrm{x} 3 \mathrm{y}}\right)$ bernilai positif sebesar 0,718 dan koefisien determinasi $\left(r^{2}{ }_{x 3 y}\right)$ sebesar 0,516 berarti bahwa Lingkungan Teman Sebaya memberikan pengaruh sebesar 51,60\% terhadap Prestasi Belajar Akuntansi Dasar dan sebesar
48,40\% dipengaruhi oleh variabel lain yang tidak diteliti.

Hasil penelitian ini diperkuat dengan kajian kajian teori dan penelitian yang relevan. Lingkungan Teman Sebaya merupakan faktor eksternal yang memengaruhi Prestasi Belajar Akuntansi Dasar. Menurut Slameto (2015:54) faktor yang ada di luar diri individu yang memengaruhi belajar salah satunya adalah relasi peserta didik dengan peserta didik, atau lingkungan dimana peserta didik berinteraksi dengan peserta didik lain yang mempunyai kesamaan usia dan status. Interaksi dengan Lingkungan Teman Sebaya dapat memberikan dampak positif maupun negatif bagi siswa terkait dengan kegiatan pembelajaran. Lingkungan Teman Sebaya yang positif akan membuat siswa lebih bersemangat dalam belajar seperti pembuatan kelompok belajar ataupun sharing terkait dengan materi pembelajaran yang telah diajarkan di kelas yang dapat meningkatkan Prestasi Belajar Akuntansi Dasar. Sebaliknya apabila Lingkungan Teman Sebaya melakukan interaksi yang berdampak negatif bagi siswa yang berkaitan dengan kegiatan belajar seperti Lingkungan Teman Sebaya membuat siswa enggan untuk belajar, maka hal tersebut akan menurunkan Prestasi Belajar Akuntansi Dasar.

Hasil penelitian ini juga diperkuat oleh penelitian ini juga diperkuat oleh penelitian yang dilakukan oleh Rosalina Dewi Pambudi (2017) yang berjudul "Pengaruh Motivasi Belajar, Disiplin Belajar, dan Lingkungan Teman Sebaya terhadap Prestasi Belajar Akuntansi Perusahaan Jasa Siswa Program Keahlian Akuntansi SMK YPKK 3 Sleman Tahun Ajaran 2016/2017". Hasil penelitian menunjukkan bahwa terdapat pengaruh positif Lingkungan Teman Sebaya terhadap Prestasi Belajar 
Akuntansi Perusahaan Jasa Siswa Program Keahlian Akuntansi di SMK YPKK 3 Sleman dengan $\mathrm{r}_{\mathrm{x} 3 \mathrm{y}}=0,627$; $\mathrm{r}^{2} \times 3 \mathrm{y}=0,393$ dan $\mathrm{t}_{\text {hitung }}=5,807>\mathrm{t}_{\text {tabel }}=$ 2,006 .

d. Pengaruh Kreativitas Belajar, Persepsi Siswa tentang Metode Mengajar Guru, dan Lingkungan Teman Sebaya secara bersama-sama terhadap Prestasi Belajar Akuntansi Dasar Siswa Kelas $X$ Akuntansi dan Keuangan Lembaga SMK Negeri 1 Pengasih Tahun Ajaran 2018/2019

Hasil penelitian ini menunjukkan bahwa Kreativitas Belajar, Persepsi Siswa tentang Metode Mengajar Guru, dan Lingkungan Teman Sebaya secara bersama-sama berpengaruh positif terhadap Prestasi Belajar Akuntansi Dasar Siswa Kelas X Akuntansi dan Keuangan Lembaga SMK Negeri 1 Pengasih Tahun Ajaran 2018/2019. Berdasarkan hasil analisis regresi ganda diperoleh persamaan garis regresi $\mathrm{Y}=0,158 \mathrm{X}_{1}+0,339 \mathrm{X}_{2}+$ $0,530 X_{3}+9,876$. Harga koefisien korelasi bernilai positif $R_{y(1,2,3)}=0,838$ dan koefisien determinasi $R^{2}{ }_{y(1,2,3)}$ sebesar 0,703 berarti bahwa Kreativitas Belajar, Persepsi Siswa tentang Metode Mengajar Guru, dan Lingkungan Teman Sebaya secara bersama-sama memberikan pengaruh sebesar 70,30\% terhadap Prestasi Belajar Akuntansi Dasar dan sebesar $29,70 \%$ dipengaruhi oleh variabel lain yang tidak diteliti. Sumbangan Relatif (SR) variabel Kreativitas Belajar sebesar $17,70 \%$, Persepsi Siswa tentang Metode Mengajar Guru sebesar 40,11\%, dan Lingkungan Teman Sebaya sebesar 42,19\% dengan jumlah keseluruhan 100\%. Besarnya Sumbangan Efektif (SE) variabel Kreativitas Belajar terhadap Prestasi Belajar Akuntansi Dasar sebesar $12,44 \%$, besarnya Sumbangan Efektif (SE) variabel Persepsi Siswa tentang
Metode Mengajar Guru terhadap Prestasi Belajar Akuntansi Dasar sebesar 28,20\%, besarnya Sumbangan Efektif (SE) variabel Lingkungan Teman Sebaya terhadap Prestasi Belajar Akuntansi Dasar sebesar $29,66 \%$, dan sebesar $29,7 \%$ berasal dari variabel lain yang tidak diteliti. Berdasarkan Sumbangan Efektif yang didapatkan, variabel Kreativitas Belajar memberikan Sumbangan Efektif yang paling kecil dibandingkan dengan variabel Persepsi Siswa tentang Metode Mengajar Guru dan Lingkungan Teman Sebaya. Variabel Lingkungan Teman Sebaya memberikan Sumbangan Efektif yang paling besar sehingga variabel Lingkungan Teman Sebaya perlu diberi perhatian yang lebih dikarenakan memiliki pengaruh yang lebih besar terhadap Prestasi Belajar Akuntansi Dasar. Berdasarkan analisis tersebut, penelitian ini sejalan dengan teori yang disampaikan oleh Yusuf dan Nurihsan (2005) dan Slameto (2015) bahwa faktor yang memengaruhi Prestasi Belajar Akuntansi Dasar diantaranya adalah Kreativitas Belajar, Persepsi Siswa tentang Metode Mengajar Guru, dan Lingkungan Teman Sebaya.

\section{SIMPULAN DAN SARAN Simpulan}

a. Terdapat pengaruh positif Kreativitas Belajar terhadap Prestasi Belajar Akuntansi Dasar Siswa Kelas X Akuntansi dan Keuangan Lembaga SMK Negeri 1 Pengasih Tahun Ajaran 2018/2019, dibuktikan dengan hasil koefisien korelasi yang bernilai positif $\mathrm{r}_{\mathrm{x} 1 \mathrm{y}}=0,589$; koefisien determinasi $\mathrm{r}^{2}{ }_{\mathrm{x} 1 \mathrm{y}}$ $=0,347$; persamaan regresi $\mathrm{Y}=$ $0,558 \mathrm{X}_{1}+32,836$; dengan thitung $=$ $5,746>t_{\text {tabel }}=1,670$, maka hipotesis pertama diterima.

b. Terdapat pengaruh positif Persepsi Siswa tentang Metode Mengajar Guru 
terhadap Prestasi Belajar Akuntansi Dasar Siswa Kelas X Akuntansi dan Keuangan Lembaga SMK Negeri 1 Pengasih Tahun Ajaran 2018/2019, dibuktikan dengan hasil koefisien korelasi yang bernilai positif $\mathrm{r}_{\mathrm{x} 2 \mathrm{y}}=$ 0,716 ; koefisien determinasi $\mathrm{r}^{2} \times 2 \mathrm{y}=$ 0,512 ; persamaan regresi $\mathrm{Y}=0,561 \mathrm{X}_{2}$ $+30,571$; dengan $\mathrm{t}_{\text {hitung }}=8,072>\mathrm{t}_{\text {tabel }}$ $=1,670$, maka hipotesis kedua diterima.

c. Terdapat pengaruh positif Lingkungan Teman Sebaya terhadap Prestasi Belajar Akuntansi Dasar Siswa Kelas $X$ Akuntansi dan Keuangan Lembaga SMK Negeri 1 Pengasih Tahun Ajaran 2018/2019, dibuktikann dengan hasil koefisien korelasi yang bernilai positif $\mathrm{r}_{\mathrm{x} 3 \mathrm{y}}=0,718$; koefisien determinasi $\mathrm{r}^{2} \mathrm{x} 1 \mathrm{y}$ $=0,516$; persamaan garis regresi $\mathrm{Y}=$ $0,927 \mathrm{X}_{3}+25,948$; dengan $\mathrm{t}_{\text {hitung }}=$ $8,123>t_{\text {tabel }}=1,670$, maka hipotesis ketiga diterima.

d. Terdapat pengaruh positif Kreativitas Belajar, Persepsi Siswa tentang Metode Mengajar Guru, dan Lingkungan Teman Sebaya secara bersama-sama terhadap Prestasi Belajar Akuntansi Dasar Siswa Kelas $X$ Akuntansi dan Keuangan Lembaga SMK Negeri 1 Pengasih Tahun Ajaran 2018/2019. Nilai koefisien korelasi bernilai positif $\mathrm{R}_{\mathrm{y}(1,2,3)=0,838 \text {; nilai }}$ koefisien determinasi $R^{2}{ }_{y(1,2,3)}=0,703$; persamaan garis regresi $\mathrm{Y}=0,158 \mathrm{X}_{1}+$ $0,339 X_{2}+0,530 X_{3}+9,876$; dengan $\mathrm{F}_{\text {hitung }}=47,310>\mathrm{F}_{\text {tabel }}=2,760$, maka hipotesis keempat diterima. Sumbangan Relatif (SR) variabel Kreativitas Belajar sebesar 17,70\%, variabel Persepsi Siswa tentang Metode Mengajar Guru sebesar $40,11 \%$, dan variabel Lingkungan Teman Sebaya sebesar 42,19\% dengan jumlah keseluruhan 100\%. Besarnya Sumbangan Efektif (SE) variabel Kreativitas Belajar sebesar 12,44\%, variabel Persepsi Siswa tentang Metode Mengajar Guru sebesar
28,20\%, dan variabel Lingkungan Teman Sebaya sebesar 29,66\% sehingga total Sumbangan Efektif (SE) yang diperoleh sebesar 70,30\%, sedangkan $29,70 \%$ berasal dari variabel lain yang tidak diteliti.

\section{Saran}

a. Bagi Guru

Pada variabel Persepsi Siswa tentang Metode Mengajar Guru berdasarkan butir pernyataan dalam angket nomor 11 dengan pernyataan "Guru menggunakan media pembelajaran yang bervariasi saat menjelaskan materi Akuntansi Dasar" memiliki jumlah skor terendah. Oleh karena itu, hendaknya guru menggunakan media pembelajaran yang bervariasi dengan disesuaikan dengan materi dan karakteristik siswa agar siswa antusias dalam mengikuti kegiatan pembelajaran sehingga tujuan pembelajaran yang telah direncanakan di awal pembelajaran dapat tercapai.

b. Bagi Siswa

1) Pada variabel Kreativitas Belajar berdasarkan butir pernyataan dalam angket nomor 14 dengan pernyataan "Saya berani memberikan masukan kepada guru terkait proses pembelajaran Akuntansi Dasar agar pembelajaran lebih baik kedepannya" memiliki jumlah skor terendah. Oleh karena itu, diharapkan siswa dapat memiliki keberanian dalam menyampaikan pendapat saat pembelajaran berlangsung. Siswa juga diharapkan berpartisipasi secara aktif di dalam kelas yaitu dengan bertanya kepada guru apabila ada materi yang belum dipahami dan menjawab pertanyaan yang diberikan oleh guru.

2) Pada variabel Lingkungan Teman Sebaya berdasarkan butir 
pernyataan dalam angket nomor 14 dengan pernyataan "Saya memilih untuk bergurau dengan teman saat jam kosong" memiliki jumlah skor terendah. Hendaknya apabila terdapat jam kosong, siswa dapat memanfaatkan waktu tersebut untuk berdiskusi dengan teman terkait dengan materi pembelajaran atau bisa dengan mengerjakan soal-soal latihan di dalam buku agar waktu kosong tersebut dapat dimanfaatkan dengan baik untuk menambah wawasan atau pengetahuan terkait materi pembelajaran.

c. Bagi Penelitian Selanjutnya

1) Penelitian ini memberikan informasi bahwa faktor Kreativitas Belajar, Persepsi Siswa tentang Metode Mengajar Guru, dan Lingkungan Teman Sebaya secara bersama-sama berpengaruh terhadap Prestasi Belajar Akuntansi Dasar Siswa Kelas X Akuntansi dan Keuangan Lembaga SMK Negeri 1 Pengasih Tahun Ajaran 2018/2019. Sumbangan Efektif (SE) yang diberikan sebesar 70,30\%. Hasil tersebut menunjukkan bahwa Prestasi Belajar Akuntansi Dasar tidak hanya dipengaruhi oleh tiga variabel yaitu Kreativitas Belajar, Persepsi Siswa tentang Metode Mengajar Guru, dan Lingkungan Teman Sebaya, namun masih banyak variabel lain yang tidak diteliti dalam penelitian ini. Oleh karena itu, diharapkan dalam penelitian selanjutnya dapat ditemukan variabel-variabel lain yang dapat memengaruhi Prestasi Belajar Akuntansi Dasar.

2) Pada variabel Prestasi Belajar Akuntansi Dasar, diharapkan penelitian selanjutnya melakukan pengujian nilai Prestasi Belajar Akuntansi Dasar menggunakan uji efektivitas pengecoh, uji beda, dan lain sebagainya. Hal ini dilakukan agar kualitas nilai Prestasi Belajar Akuntansi Dasar yang digunakan terjamin kevalidannya sehingga nilai tersebut benar-benar mencerminkan Prestasi Belajar Akuntansi Dasar yang diperoleh siswa.

\section{DAFTAR PUSTAKA}

Arikunto, S. (2013). Prosedur Penelitian Suatu Pendekatan Praktik. Jakarta: PT Rineka Cipta.

Desmita. (2016). Psikologi Perkembangan. Bandung: PT Remaja Rosdakarya.

Irfa', A. (2017). Pengaruh Motivasi Belajar, Kreativitas Belajar, dan Lingkungan Teman Sebaya terhadap Prestasi Belajar Akuntansi Keuangan Siswa Kelas X Akuntansi SMK Negeri 1 Tempel Tahun Ajaran 2016/2017. Skripsi. FE UNY.

Kemenristekdikti. (2015).Peraturan Pemerintah Republik Indonesia Nomor 13, Tahun 2015, tentang Perubahan Kedua atas Peraturan Pemerintah Nomor 19 Tahun 2005 tentang Standar Nasional Pendidikan.

Nugroho, B. A. (2006). Strategi Jitu Memilih Metode Statistik Penelitian dengan SPSS. Yogyakarta: Penerbit Andi.

Pambudi, R. W. (2017). Pengaruh Motivasi Belajar, Disiplin Belajar, dan Lingkungan Teman Sebaya terhadap Prestasi Belajar Akuntansi Perusahaan Jasa Siswa Program Keahlian Akuntansi di SMK YPKK 3 Sleman Tahun Ajaran 2016/2017. Skripsi: FE UNY. 
Palupi, H. N. (2018). Pengaruh Lingkungan Keluarga, Minat Belajar, dan Persepsi Siswa tentang Metode Mengajar Guru terhadap Prestasi Belajar Akuntansi Dasar Siswa Jurusan Akuntansi SMK Abdi Negara Muntilan Tahun Ajaran 2017/2018. Skripsi: FE UNY.

Siswoyo, D, dkk. (2013). Ilmu Pendidikan. Yogyakarta: UNY Press.

Slameto. (2015). Belajar dan Faktorfaktor yang Memengaruhinya. Jakarta: PT Rineka Cipta.
Sudjana, N. (2004). Dasar-dasar Proses Belajar Mengajar. Bandung: Sinar Baru Algensindo

Sugiyono. (2015). Metode Penelitian Pendidikan: Pendekatan Kuantitatif, Kualitatif, dan $R \& D$. Bandung: Alphabeta.

(2015). Statistika untuk Penelitian. Bandung: Alphabeta.

Yusuf, S \& Nurihsan, J. (2005). Landasan Bimbingan dan Konseling. Bandung: PT Remaja Rosdakarya. 